\title{
Stenographic Learning Video: Design And Analysis of Video Production Using And Without Using The Script
}

\author{
Riski Acibi Kuncoro*, Evaliata BR Sembiring*, Shinta Wahyu Hati** \\ *Multimedia and Network Engineering, Batam State Polytechnic \\ **Applied Business Administration
}

\begin{abstract}
Article Info
Article history:

Received Oct $12^{\text {th }}, 2020$

Revised Nov $20^{\text {th }}, 2020$

Accepted Dec $10^{\text {th }}, 2020$

\section{Keyword:}

Learning media

Video

Script

ABSTRACT

The selection of the right learning media is one of the factors so that students can easily understand the material being discussed. One of them is by using video learning media. Producing a video script design becomes the basis for consideration in the video-making process. The script is the main reference or a guide in conducting video production activities. The activity of producing a video without using a script is a waste of nothing. So, research was made to produce a stenography learning video using a script and without a script. This research was made using the R\&D (Research \& Development) research method which will then be analyzed the comparison of the results of the two videos using qualitative analysis with a comparative model. The results obtained showed that the use of texts influences the process of learning video production compared to the results obtained. So the production of stenography learning videos using scripts is more effective than without using scripts.
\end{abstract}

Copyright $@ 2020$ Institute of Advanced Engineering and Science. All rights reserved.

Teknik Multimedia Jaringan, Jurusan Teknik Informatika,

Politeknik Negeri Batam

Batam Centre, Jl. Ahmad Yani, Tlk. Tering, Kec. Batam Kota, Kepulauan Riau 29461

Email: eva@polibatam.ac.id

\section{INTRODUCTION}

The rapid development of science and technology has a positive impact on the development of education. This happens not only at the level of basic education but also at the level of higher education. Various efforts have been made so that the quality and quantity of education can be improved, both in curriculum development, learning innovation, and fulfillment of the necessary facilities and infrastructure. The selection of appropriate learning media is one of the factors so that students easily understand the discussion of the material presented. Media that is often used in learning stenography is through books and modules. Books and modules often make students feel bored, bored and lazy because the contents and delivery methods are less attractive.

Stenography means short writing [1]. Writing stenography is one of the skills that a secretary or administrator must possess. By possessing this skill, confidential records can be written securely without many people knowing. So far the teacher, in delivering stenographic learning, is only limited to the use of one learning medium, namely books and modules. Also, the existence of educational innovations in the form of renewal in the field of curriculum, methods, and learning models is one way to improve the quality of education, one of which is by using stenographic learning media in the form of videos.

In general, in producing a video there are several stages of the process, namely development, pre-production, production, post-production, and distribution [2]. Development is the process of collecting and developing ideas. Preproduction is the process of developing scripts, storyboards, scheduling, etc. The production is in the form of recording. Post-production is the process of editing and combining the results of the process being passed and the distribution of marketing processes.

From these stages, the pre-production stage is important. In this stage, the success of the next stage is determined, one of which is the design of the script which is the basis for consideration in the process of making videos. The script is a written result that becomes material in making videos that contain details of production-ready material from the angle of view in detail and specific as well as other parts of activities [3]. Manuscripts are made before the process of taking and editing images. Many people who want to make videos skip this part of making scripts 
and think this is not important. The activity of producing a video without using a script is a waste of time because the script itself is the main reference or a guide in conducting video production activities [4].

Based on the problems mentioned earlier, the question arises on how to produce instructional videos on stenography courses using scripts and without scripts and how to analyze the comparison of video results using scripts and without scripts. So in this research, a stenography learning video production will be done using a script and without a script. Then the results of the two videos will be analyzed. The purpose of this research is to produce a live video as a learning media for stenography and find out the comparison of the results of the live video that uses a script and without a script. This research was made using the RnD (Research and Development) research method with the Villamil-Molina development model. Multimedia development will be successful by requiring careful planning, mastery of good multimedia technology, and mastery of good production management [5]. Villamil-Molina development consists of five stages, namely Development, Preproduction, Production, Postproduction, and Delivery. Next this study will analyze the comparison of the results of the two videos using qualitative analysis with a comparative model. It is hoped that the results of this study can be considered in making videos so that the videos produced are following what was planned.

\section{RESEARCH METHOD}

The method used in this research is the R\&D (Research \& Development) method. R\&D research is used when research is conducted to produce a particular product and then tested the effectiveness of the product [6]. The stages of multimedia research in this study are presented in detail in Figure 1.

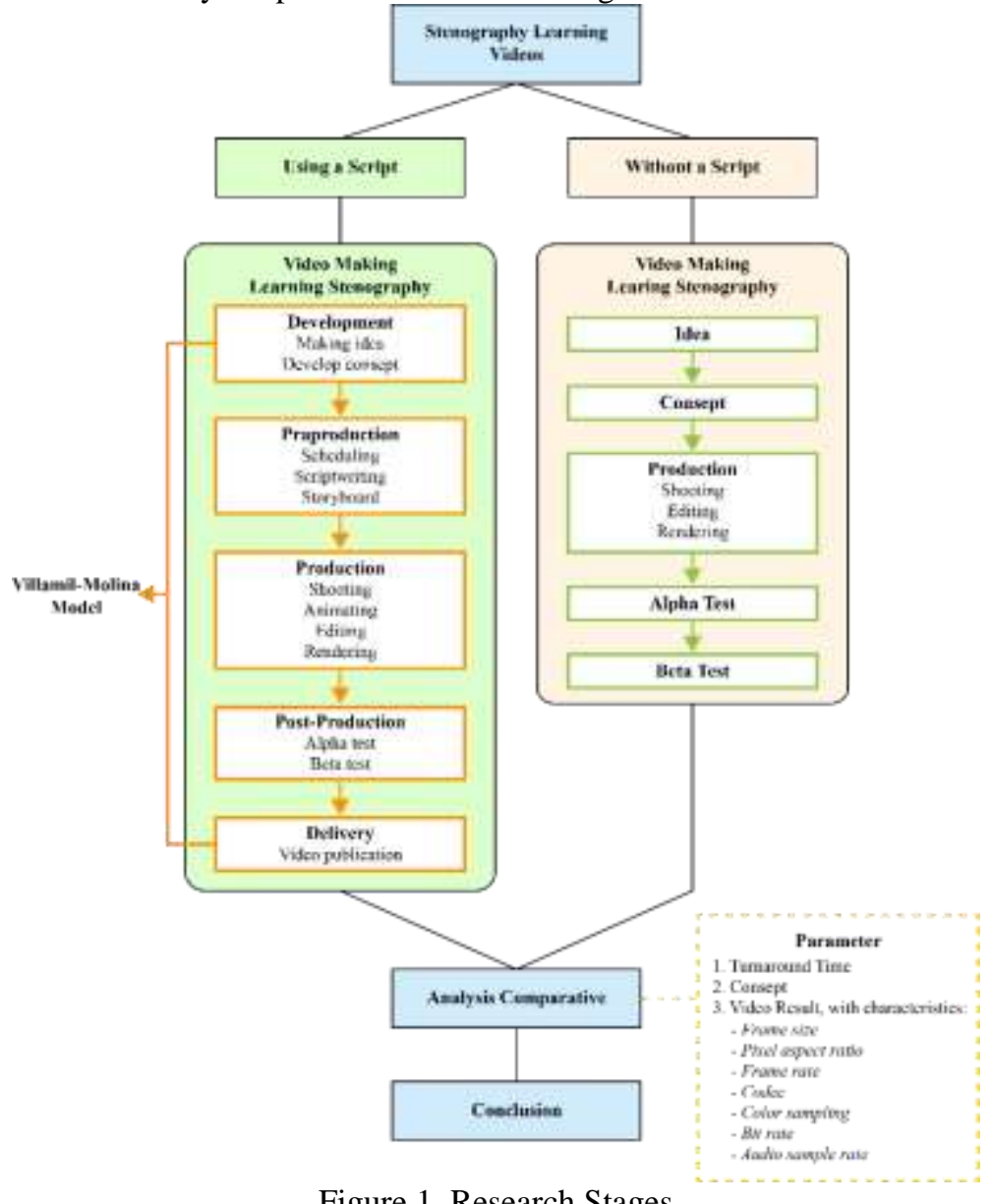

Figure 1. Research Stages

\subsection{Video Production Using Script}

1) Development

This stage consists of ideas and concepts of stenographic learning videos.

a) Idea

The idea of making this stenography learning video is because so far the delivery of stenographic learning is only limited to using books or modules. Books and modules often make students feel bored, bored, and lazy 
because the contents and delivery methods are less attractive. Meanwhile, the rapid development of science and technology has a positive impact on the development of education not only in basic education but even in tertiary institutions.

b) Concept

Making a stenography learning video is done by combining video with motion animation and background music. The lecturer video explaining the stenographic material was taken at the broadcasting studio with a green screen background. Later the green screen is replaced using a slightly blurry background image. Then added to the animation in the form of motion text, shapes, and images and audio music as video support to be made. Video, animation, and music audio files will be processed using Adobe Premiere software which will be converted into .mp4 format and can be played with video player software such as VLC, MP-HC, Windows Media Player, and so on.

\section{2) Praproduction}

This stage is the initial stage in the planning of making stenographic learning videos namely by making work schedules as a reference in conducting research, scriptwriting as a guide in carrying out production, and making storyboards as an illustration in the form of scenes in the video.

\section{a) Scheduling}

Scheduling activities are carried out to make plans for carrying out research activities to run optimally and efficiently. This production process is carried out for 6 months.

\section{b) Scripwriting}

The activities carried out at this stage are making synopsis, treatments, and scripts for stenographic learning videos. A piece of the script can be seen in table 1 .

Table 1. Script Fragments

\begin{tabular}{|c|c|c|c|}
\hline Scene & Shot & Script & Visual \\
\hline 1 & MS & $\begin{array}{l}\text { Halo. Selamat Datang Kembali di Mata Kuliah Stenografi. } \\
\text { Perkenalkan saya Shinta Wahyu Hati. }\end{array}$ & $\begin{array}{l}\text { Insert Motion Text: } \\
\text { Stenografi } \\
\text { Insert Motion Text: } \\
\text { (Shinta Wahyu Hati, S.Sos, M.AB) - } \\
\text { Politeknik Negeri Batam }\end{array}$ \\
\hline 2 & MS & $\begin{array}{l}\text { Di video kali ini kita akan membahas mengenai Huruf Bulat } \\
\text { Stenogrfi. }\end{array}$ & $\begin{array}{l}\text { Insert Slide: } \\
\text { Huruf Bulat Stenografi }\end{array}$ \\
\hline 3 & MS & $\begin{array}{l}\text { Bentuk Huruf Bulat yang biasanya juga disebut sebagai huruf } \\
\text { bulat adalah huruf konsonan dalam stenografi. }\end{array}$ & $\begin{array}{l}\text { Insert Motion Text: } \\
\text { Bentuk Huruf Bulat = Huruf Konsonan }\end{array}$ \\
\hline & & $\begin{array}{c}\text { Biasanya para mahasiswa yang sedang belajar stenografi agak } \\
\text { mengalami kesulitan dalam memahaminya. Mari kita simak } \\
\text { pejelasan Huruf Bulat Stenografi lebih lanjut. }\end{array}$ & $\begin{array}{l}\text { Insert Motion Text dan Gambar: } \\
\text { Stenografi + Gambar Mahasiswa + ??? }\end{array}$ \\
\hline
\end{tabular}

c) Storyboard

At this stage is the creation of storyboards designed for making stenographic learning videos. The storyboard consists of 13 scenes and 40 frames which can be seen in table 2 fragments of the storyboard.

Table 2. Storyboard Fragments

\begin{tabular}{lll}
\hline Scene Frame & \multicolumn{1}{c}{ Information } \\
\hline 1 & $\begin{array}{l}\text { Duration: } 10 \text { secconds } \\
\text { Shot Size: MS } \\
\text { Angle Cam: Center } \\
\text { Audio: backsound.mp3 } \\
\text { Info: } \\
\text { This scene shows the lecturer who started opening and } \\
\text { introducing himself. Then display the stenographic motion text } \\
\text { and the name of the lecturer. }\end{array}$ & $\begin{array}{l}\text { Duration: } 6 \text { seconds } \\
\text { Shot Size: MS } \\
\text { Angle Cam: Center } \\
\text { Audio: backsound.mp3 } \\
\text { Info: } \\
\text { This secene displays the motion text and shape material of } \\
\text { round stenographic letters. }\end{array}$ \\
&
\end{tabular}




\begin{tabular}{ccl}
\hline Scene & Frame & \multicolumn{1}{c}{ Information } \\
\hline 3 & 1 & $\begin{array}{l}\text { Durasi: 15 detik } \\
\text { Shot Size: MS } \\
\text { Angle Cam: Center } \\
\text { Audio: backsound.mp3 } \\
\text { Ket: } \\
\text { scene ini menampilkan dosen yang bergeser ke kanan. Di } \\
\text { sebelah kirinya menampilkan motion text huruf bulat dan huruf } \\
\text { konsonan. Lalu motion tersebut mengecil sedikit dan pindah } \\
\text { keatas sekaligus muncul gambar mahasiswa yang bingung } \\
\text { dengan tanda tanya di atas kepalanya. }\end{array}$ \\
\end{tabular}

\subsection{Video Production Without Script}

1) Idea

The idea of making this stenography learning video is because so far the delivery of stenographic learning is only limited to using books or modules. Books and modules often make students feel bored, bored, and lazy because the contents and delivery methods are less attractive. Meanwhile, the rapid development of science and technology has a positive impact on the development of education not only in basic education but even in tertiary institutions.

\section{2) Consept}

This stenography learning video is a merging video with background music. The making of stenography learning videos is done in the classroom. Then the video files and background music will be processed using Adobe Premiere software which will be converted into .mp4 format and can be played with video player software such as VLC, MP-HC, Windows Media Player, and so on.

\section{HASIL DAN ANALISIS}

For video production using a script based on the Villamil-Molina model applied in this study, namely production, post-production, and delivery. And for video production without using a script in this study, namely production, alpha testing, and beta testing. Furthermore, this chapter will also conduct an analysis using comparative model analysis.

\subsection{Video Production Using Script \\ 1) Production}

Some of the stages carried out in this production process are shooting, animating, editing, and rendering to produce stenographic learning videos as illustrated in Figure 2. In the animating section loading objects and making animations as well as editing the video editing, inserting animations, and inserting back sound.

\section{2) Post Production}

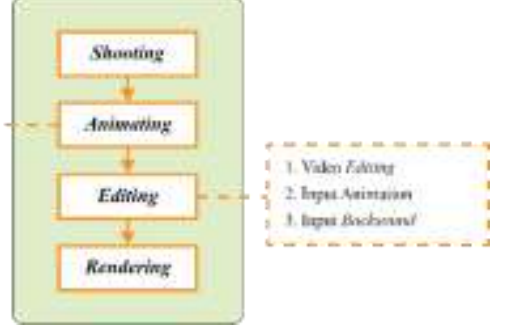

Figure 2. Illustration of Video Production Using a Script

In the post-production stage, an alpha test is used to adjust the initial draft in the form of a script with the product results obtained if there are changes. Then the test is called a beta test in the form of validation from the speaker regarding the concept of learning videos to ensure the suitability of the material presented.

\section{a) Alpha Test}

Alpha test is done by testing the finished product based on the script During the testing process, some changes occur due to some input from the client during the process of taking pictures and editing takes place. A piece of the results of the script changes with the completed learning video presented in table 3 is marked by giving bold and underlined styles.

Table 3. Changes

\begin{tabular}{llcc}
\hline Scene Shot & Script & Implementation Results \\
& & Visual \\
\hline
\end{tabular}




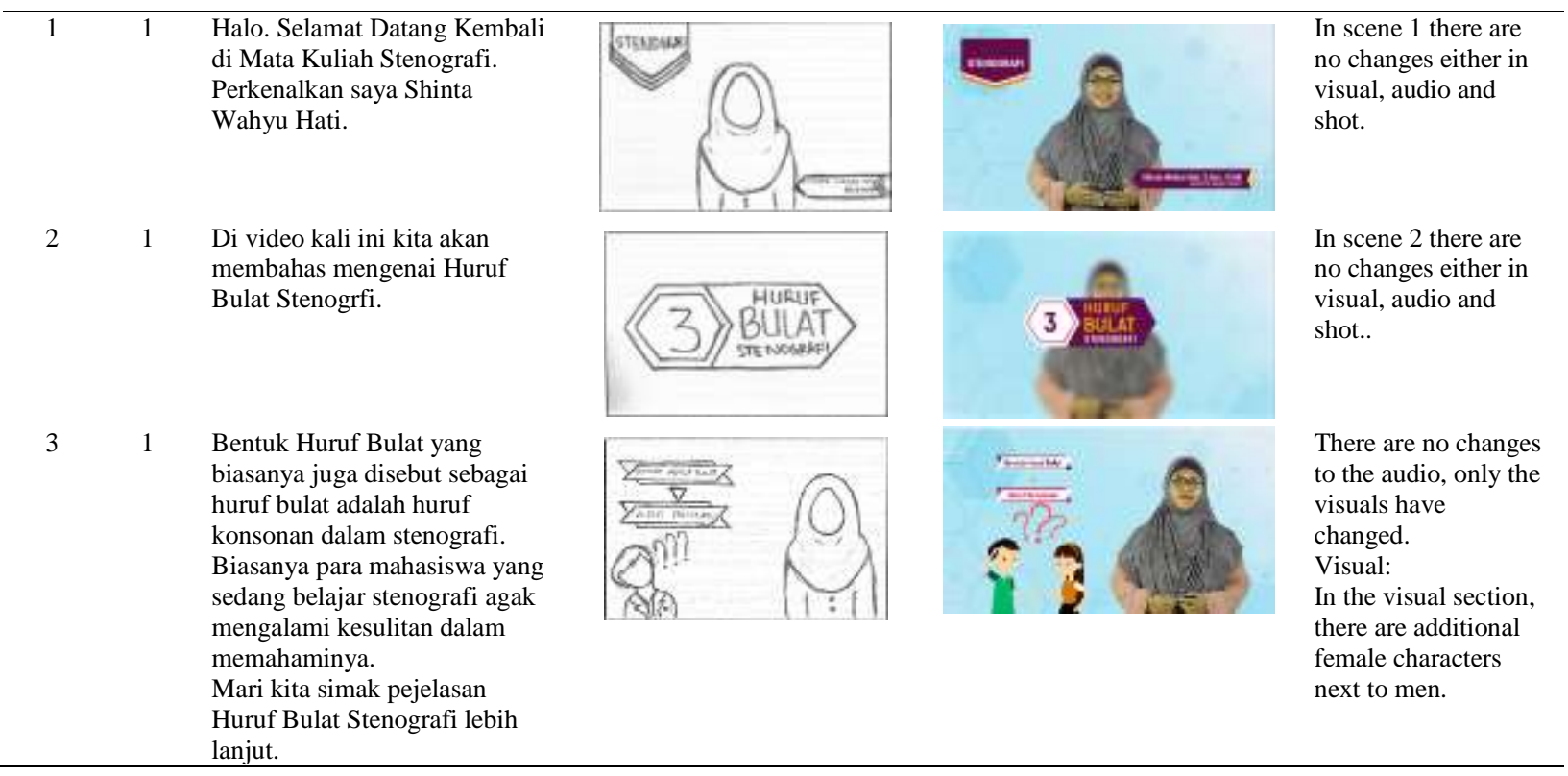

The final amendment of the script with the total scene produced is 13 scenes and 40 frames with a video duration of 8 minutes 42 seconds and the .mp4 format. Of the 13 scenes, there are 4 scenes that do not change, namely scenes $1,2,12$, and 13. Changes in audio occur not much, the narrator adds words or sentences according to the needs that exist in the field (during the shooting process) while changes in visuals occur by adjusting the layout to suit the needs (during the editing process). From table 3 it can be seen that the dominant script changes occur in the visual part, but do not change information or sentences.

b) Beta Test

The beta test is carried out by conducting a validation test regarding the learning video content to ensure the suitability of the material presented. The beta test is conducted by presenters of stenography courses from the Applied Business Administration Study Program. The validation instrument used in the form of a questionnaire consisted of 8 main aspects of assessment namely ideas, goals, video duration, clearly readable writing, clearly audible audio, video running format, the material according to the RPS, and delivery of material. Based on the results of the validation it can be said that all aspects of the assessment of the content 3) Delivery of the stenographic learning video using the script have been approved and can be displayed to the public.

Learning videos are saved using the .mp4 format. The publication of this video through the Batam Polytechnic State E-Learning, particularly the Applied Business Administration Study Program, can be seen by students for the learning process.

\subsection{Video Production Without Script}

\section{1) Production}

Some of the stages carried out in this production process are shooting, editing, and rendering to produce stenographic learning videos as illustrated in Figure 4. In the editing section video editing and back sound.

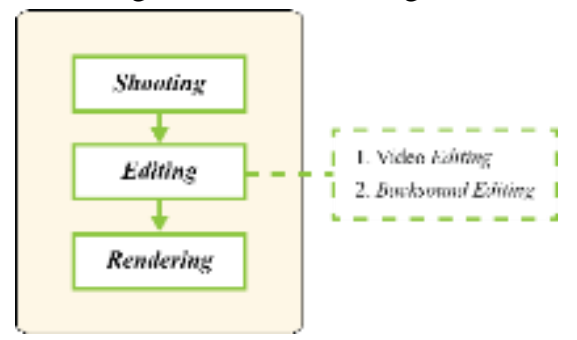

Figure 4. Illustration of Video Production Without a Script

\section{2) Alpha Test}

Alpha test is carried out by developers by testing finished products based on ideas and concepts. During the alpha test process, there were some improvements to the editing process for some client input. This causes the editing process to be done repeatedly which takes a long time to fix. 


\section{3) Beta Test}

The beta test is carried out by conducting a validation test regarding the learning video content to ensure the suitability of the material presented. The beta test is conducted by presenters of stenography courses from the Applied Business Administration Study Program. Validation instruments used in the form of a questionnaire consisting of 8 main aspects of assessment namely ideas, goals, video duration, writing read, audio heard, the format of running the video, the material according to the RPS, and delivery of material Based on the validation results can be said that the learning video stenography without a script has not been approved and can not be displayed to the public because there are aspects that are not approved.

\subsection{Analysis of Video Production and Results}

Comparative analysis of the production and results of instructional videos using a script and without using a script with two parameters for the production of stenographic learning videos namely completion time and concepts, as well as video characteristic parameters for the results of stenographic learning videos. Then testing the hypothesis using paired sample t-test.

\section{1) Video Production}

\section{a) Scheduling}

The video production process using a script takes 17 days. The process of learning video production using the script is faster because the stages carried out to be done have been arranged according to the initial design made based on the script by the RPS of stenography courses. Only when making animation does it take time to adjust the colors to be used. As for the video production process without using a script of completion for 21 days due to difficulties in the shooting and editing process. Shooting is done without a draft in the beginning to make the process of taking pictures improperly, causing the editing process to take a long time. This happens because the video has undergone several reviews that require editing repeatedly.

\section{b) Consept}

The implementation of this concept test is done by validating the concept of video learning stenography using a script and without using a script. The validators in this validation are presenters of stenography courses who have conducted beta tests before. Based on the results of the validation there are several opinions as seen in table 4 for the results of the evaluation using the manuscript and table 5 for the results of the assessment without the manuscript.

Table 4. Assessment Results Using Manuscripts

\begin{tabular}{clcc}
\hline No & \multicolumn{1}{c}{ Assessment Aspects } & Validator 1 & Validator 2 \\
\hline 1 & Idea planned. & Yes & Yes \\
2 & Destination determined. & Yes & Yes \\
3 & Video length is correct. & Yes & Yes \\
4 & The writing on the video can be read clearly. & Yes & Yes \\
5 & Material in the video is according to RPS. & Yes & Yes \\
6 & Stenographic material is delivered in accordance with the & Yes & Yes \\
& design. & & Yes \\
8 & The audio in the stenography learning video sounds clear. & Yes & Yes \\
\hline
\end{tabular}

Table 5. Assessment Results Without Manuscripts

\begin{tabular}{clcc}
\hline No & \multicolumn{1}{c}{ Assessment Aspects } & Validator 1 & Validator 2 \\
\hline 1 & Idea planned. & No & No \\
2 & Destination determined. & No & Yes \\
3 & Video length is correct. & No & Yes \\
4 & The writing on the video can be read clearly. & Yes & No \\
5 & Material in the video is according to RPS. & Yes & Yes \\
6 & Stenographic material is delivered in accordance with the & Yes \\
& design. & No & No \\
8 & The audio in the stenography learning video sounds clear. & Yes & Yes \\
\hline
\end{tabular}

\section{2) Video Characteristics}

Stenography learning videos are run using the MPC-HC media player application. The results of a comparison of stenographic learning videos using a script and without using a script based on 7 video characteristics can be seen in table 6 . 


\begin{tabular}{|c|c|c|c|c|}
\hline No & Parameter & Video Using a Script & Video Without a Script & Information \\
\hline 1 & Frame Size & $1920 \times 1080$ pixels & $1280 \times 720$ pixels & Different \\
\hline 2 & Pixel aspect ratio & $16: 9$ & $16: 9$ & Same \\
\hline 3 & Frame rate & 25.000 FPS & 25.000 FPS & Same \\
\hline 4 & Codec & mp42 (mp42/mp41) & mp42 (mp42/mp41) & Same \\
\hline 5 & Color sampling & $4: 2: 0$ & $4: 2: 0$ & Same \\
\hline 6 & Bit rate & 14.7 Mb/s (video), $192 \mathrm{~kb} / \mathrm{s}$ (audio) & $5997 \mathrm{~kb} / \mathrm{s}$ (video), $192 \mathrm{~kb} / \mathrm{s}$ (audio) & Different \\
\hline 7 & Audio sample rate & $48.0 \mathrm{kHz}$ & $48.0 \mathrm{kHz}$ & Same \\
\hline
\end{tabular}

From the 7 video characteristics used there are 5 similar characteristics, namely pixel aspect ratio, frame rate, codec, color sampling, and audio sample rate and 2 different characteristics namely frame size and bit rate.

\section{CONCLUSION}

Based on the results and discussion obtained, it can be concluded the results of the study are as follows: (1) Video on learning stenography using a script and without a script successfully made by the design. (2) The resulting product has a different duration, that is, a stenography learning video without a script is longer than a stenography learning video using a script. (3) The use of texts influences the learning video production process compared to the results obtained. (4) Stenography learning video production using a script is more effective than without using a script.

\section{ACKNOWLEDGEMENTS}

Thank you to the Batam State Polytechnic, especially to Mrs. Evaliata BR. Sembiring, S.Kom., M.Cs., who has guided and supported this research, Ms. Shinta Wahyu Hati, S. Sos., M.AB., who has helped provide advice and input to this a.

\section{REFERENCES}

[1] Rusdiyanto, W., 2013, Persepsi Guru Administrasi Perkantoran Terhadap Stenografi di SMK Negeri Kelompok Bisnis dan Manajemen Se-Kabupaten Sleman. Yogyakarta: Fakultas Ekonomi UNY.

[2] Cleve, B., 2006, Film Production Management (Third Edition), London: Focal Press London.

[3] Effendy, H., 2002, Mari Membuat Film: Panduan Menjadi Produser, Yogyakarta: Panduan.

[4] Sutisno, 1993, Pedoman Praktis Penulisan Skenario Televisi dan Video, Jakarta: Gramedia.

[5] Binanto, I., 2013, Perbandingan Metode Pengembangan Perangkat Lunak Multimedia, In Prosiding Seminar RiTekTra 2013, Teknik Informatika, Fakultas Sains dan Teknologi, Universitas Sanata Dharma.

[6] Sugiyono, 2017, Metode Penelitian Kuantitatif, Kualitatif, dan R\&D, Bandung: Alfabeta. 